OPEN ACCESS

Edited by: Kenneth Walsh,

Boston University School of Medicine, USA

Reviewed by:

Tanja Zeller,

University of Hamburg, Germany loakim Spyridopoulos,

Newcastle University, UK

${ }^{*}$ Correspondence:

Hyo-Soo Kim

hyosoo@snu.ac.kr

Specialty section:

This article was submitted to Atherosclerosis and Vascular

Medicine,

a section of the journal

Frontiers in Cardiovascular Medicine

Received: 09 August 2016 Accepted: 08 November 2016 Published: 24 November 2016

Citation:

Kang J, Kim T-W, Hur J and Kim H-S (2016) Strategy to Prime the Host and Cells to Augment Therapeutic

Efficacy of Progenitor Cells for

Patients with Myocardial Infarction.

Front. Cardiovasc. Med. 3:46. doi: 10.3389/fcvm.2016.00046

\section{Strategy to Prime the Host and Cells to Augment Therapeutic Efficacy of Progenitor Cells for Patients with Myocardial Infarction}

\author{
Jeehoon Kang 1,2, Tae-Won Kim ${ }^{2,3}$, Jin Hur ${ }^{3}$ and Hyo-Soo Kim ${ }^{1,2,3 *}$ \\ 'Department of Medicine, Seoul National University Hospital, Seoul, South Korea, ${ }^{2}$ Molecular Medicine \& Biopharmaceutical \\ Science, Graduate School of Convergence Science \& Technology, Seoul National University, Seoul, South Korea, \\ ${ }^{3}$ National Research Laboratory for Stem Cell Niche, Center for Medical Innovation, Seoul National University Hospital, Seoul, \\ South Korea
}

Cell therapy in myocardial infarction (MI) is an innovative strategy that is regarded as a rescue therapy to repair the damaged myocardium and to promote neovascularization for the ischemic border zone. Among several stem cell sources for this purpose, autologous progenitors from bone marrow or peripheral blood would be the most feasible and safest cell-source. Despite the theoretical benefit of cell therapy, this method is not widely adopted in the actual clinical practice due to its low therapeutic efficacy. Various methods have been used to augment the efficacy of cell therapy in MI, such as using different source of progenitors, genetic manipulation of cells, or priming of the cells or hosts (patients) with agents. Among these methods, the strategy to augment the therapeutic efficacy of the autologous peripheral blood mononuclear cells (PBMCs) by priming agents may be the most feasible and the safest method that can be applied directly to the clinic. In this review, we will discuss the current status and future directions of priming PBMCs or patients, as for cell therapy of MI.

Keywords: cell therapy, myocardial infarction, priming agents, peripheral blood mononuclear cells, MAGIC cell therapy

\section{INTRODUCTION}

Ischemic heart disease is one of the leading causes of death worldwide. Beyond the current practice guidelines of percutaneous coronary intervention and standard medication for acute myocardial infarction (MI; consisting of aspirin, clopidogrel, heparin, and abciximab), how to preserve or repopulate cardiomyocytes during the necrotic process of infarction has been left as an unsolved issue. Along with the boost of stem cell biology, preclinical studies have shown positive and optimistic results of stem or progenitor cells to repair ischemic limb or myocardium $(1,2)$, which brought great expectation that these therapies could rescue cardiomyocytes damage, enhance vascular density, and eventually rebuild the necrotic myocardium. Also, early human studies showed a decrease in the infarct size after MI by implantation of bone marrow stem cells (3). During the past decade, many clinical trials showed positive results of cell therapy (4-7), while other clinical studies showed no beneficial effect of cell therapy over placebo $(8,9)$. Meta-analyses have been reported, trying to give a clear answer to the question about the efficacy of stem cell therapy (10-12). These meta-analyses also have shown conflicting results due to the large heterogeneity of clinical trials of stem cell therapy 
(i.e., cell type, delivery mode, timing of infusion, endpoint, and follow-up period). Until now, the accumulated evidence from the relatively homogenous clinical trials, which used autologous bone marrow monocytes or peripheral blood progenitors mobilized from bone marrow for patients with acute MI, indicates that the effect of stem cell therapy is proved, but its efficacy is modest.

The theoretical background of stem cell therapy is the pluripotency and plasticity of stem cells that undergo transdifferentiation into mature cells and repair the damaged tissue (13). A wide variety of cell types are used, including bone marrow mononuclear cells (BM-MNC), endothelial progenitor cells (EPCs), peripheral blood mononuclear cells (PBMCs), peripheral blood mobilizedprogenitor-cells from bone marrow (PB-MPCs), mesenchymal stem cells, cardiac stem cells, etc. Also, various methods are used to augment the efficacy of stem cell therapy, such as genetic manipulation, or non-genetic cytokine/chemokine priming the cells/hosts, or ex vivo expansion of cells. Genetic manipulation can be performed either by direct transfer of genes into the host (using retroviruses or adenoviruses) or by using living cells as vehicles to transport the genes of interest. Priming can be done with various cytokines/chemokines, by direct injection to the host or by ex vivo application of the priming agent on cells. After preparation of stem cells, these cells can be delivered directly to the damaged tissue, by systemic injection or by intracoronary injection in the case of ischemic heart disease (14).

Among various methods for stem cell therapy, PB-MPCs are the most feasible and practical cell type, due to the comparable efficacy to bone marrow progenitors and the non-invasive method of collection compared to bone marrow progenitors. However, PB-MPCs have shown limited efficacy, probably owing to the low homing-efficiency, the poor long-term survival rate of infused cells, and the potential dysfunction of PB-MPCs $(15,16)$. In this review, we will discuss a method to enhance the therapeutic efficacy of PB-MPCs, called "priming," and the various non-genetic agents/conditions used to prime the infused cells or the patients themselves. Also, we will introduce recent clinical trials and ongoing trials for stem cell therapy in MI, along with a current trial conducted by our institute.

\section{RATIONALE FOR CELL THERAPY IN MI}

After an ischemic insult in the myocardium, endogenous repair would be minimal or insufficient. The various cell types including cardiomyocytes and stem cells within or out of heart participate in this endogenous repair process (17). However, this is not sufficient to prevent deleterious remodeling, leading researchers to pursue exogenous cell delivery to achieve the substantial degree of cardiac regeneration. The best-case scenario would be that the delivered cells differentiate into functional cardiomyocytes and replace the necrotic tissue, which turned out to be unachievable due to the low retention rate and limited differential potential of injected cells (18). Therefore, the aim of current cell therapy has been established to improve myocardial perfusion through neovascularization, modulate the inflammatory response by ischemia, and correct metabolic and electromechanical disturbances (19). Currently, it is well recognized that the prominent mechanism of the beneficial effect of cell therapy involves the activation of endogenous healing pathways through paracrine factors. These pathways can improve the survival of cardiomyocytes and activate recruitment of endogenous stem cells (17). Also, cell therapy aids angiogenesis to the damaged myocardium by either direct differentiation or by activating endogenous angiogenic progenitors (20). Overall, the goal for cell therapy is more to achieve a niche favorable for regeneration, rather than for direct differentiation to cardiomyocytes.

\section{VARIOUS PRIMING AGENTS FOR PBMCs OR PB-MPCs}

Currently, various cell types have been studied for cell therapy in MI. Among them, the most commonly used cells are BM-MNCs, PBMCs, or PB-MPCs containing stem cells mobilized from bone marrow by mobilizers such as subcutaneous injection of granulocyte colony-stimulating factor (G-CSF) (21). To augment the therapeutic efficacy of these cells, strategy to prime the cells by direct exposure to the priming agent or to prime the patients by systemic administration of the priming agent is a useful and practical method in the clinic. Major priming agents include G-CSF, angiopoietin-1 (Ang-1), erythropoietin (EPO), activated platelet supernatant (APS), growth factors such as SDF-1 and vascular endothelial growth factor (VEGF), and conditions such as hypoxia. The action mechanism of these agents is the induction of many genes that can induce angiogenesis, control inflammation, and promote tissue regeneration, leading to the enhanced therapeutic efficacy of stem cells. The following are preclinical study results explaining the mechanism of major agents or conditions that have been used for priming of cell or host (Figure 1).

\section{Granulocyte Colony-Stimulating Factor}

Granulocyte colony-stimulating factor is a well-known agent that potently mobilizes hematopoietic stem cells from the bone marrow (22). G-CSF acts via the activation of the G-CSF receptor, which initiates maturation, survival, proliferation, and functional activation of granulocytes (23). The most critical factor determining the therapeutic efficacy of mobilization using G-CSF may be the homing of mobilized PBMCs or PB-MPCs, which is mediated by the SDF-1/CXCR4 axis (24). Several mechanisms have been reported for G-CSF itself to help repair the damaged myocardium, such as, apoptosis inhibition (25), induction of angiogenesis (26), anti-inflammatory effects (27), modulation of extracellular matrix (28), and many other paracrine effects (29).

Until now, several human clinical trials have evaluated the safety and efficacy of G-CSF injection in patients with acute MI, where they tested the effect of G-CSF to prime the host or patient, but not the effect of cell-priming or mobilization effect. Some trials have shown positive results (30-32), while others have failed to confirm the above beneficial effects of G-CSF in patients with acute MI (33-35). Disappointingly, meta-analyses showed that G-CSF therapy was not associated with any significant benefit in left ventricular systolic function, whereas subgroup analyses suggested that G-CSF therapy might be beneficial in selected patients 


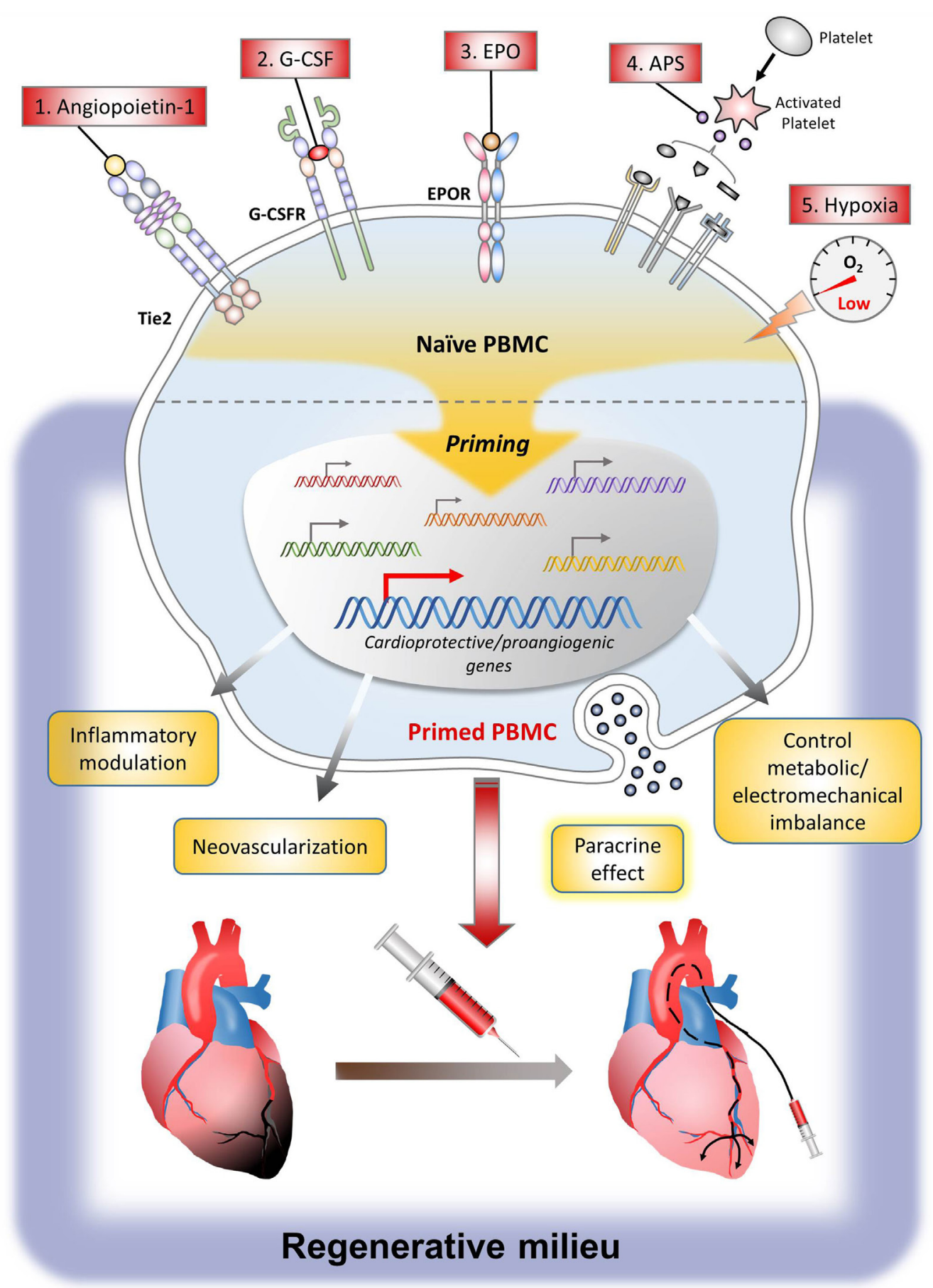

FIGURE 1 | Scheme of the cellular effects of priming agents.

$(36,37)$. But, these negative or conflicting results do not deny the efficacy of G-CSF as a mobilizer of progenitor from bone marrow to peripheral blood or as a cell-priming agent.

\section{Angiopoietin-1}

Angiopoietin-1 is a growth factor binding to the Tie2 receptor expressed on endothelial cells and hematopoietic stem cells.
Through the Tie2 signaling, Ang-1 plays an essential role in postnatal angiogenesis by mediating vessel maturation and maintaining vessel integrity (38). In a previous preclinical study, we found that most of the PB-MPCs had Tie2 receptor and that short-term Ang-1 exposure induced PB-MPCs to differentiate into endothelial lineage through the Tie2/Ets-1 signaling pathway. This eventually enhanced the neovasculogenic potential in 
the ischemic tissue (39). Additionally, short-term Ang-1 priming induced PB-MPCs to express $\alpha 4, \alpha 5$, and $\beta 1$ integrins that were also downstream targets of Ets-1. These in vitro results are important because the weakest point of intra-arterial delivery of progenitors to myocardium is the poor retention rate. PB-MPCs that were primed with Ang-1 become "sticky," leading to significant improvement of retention efficiency and therapeutic efficacy after intra-arterial delivery. The process of applying Ang-1 to the clinic is ongoing by producing human-grade Ang-1 protein in an economically feasible way.

\section{Erythropoietin}

Erythropoietin, a glycoprotein hormone produced primarily by the kidney, is a well-known cytokine that controls erythropoiesis (40). Therapeutically, EPO is commonly used as a treatment for anemia in patents with renal failure or hematologic disorders. At the cellular level, EPO acts through the EPO receptor, which changes its conformation upon binding with EPO. This results in phosphorylation of JAK2 kinases, leading to the activation of numerous intracellular signaling cascades, such as the JAK/STAT, PI3-kinase/Akt, and MAPK pathway (41).

Due to its cellular effect (i.e., enhanced proliferative, vasculogenic, and anti-apoptotic properties) (42), EPO has been used in clinical trials as a host-priming agent in MI patients, so as to decrease infarct size and preserve cardiac function. However, the results were disappointing, showing conclusions that EPO did not reduce myocardial infarct size (43-45). This discrepancy between the positive cellular effect and negative results in clinical trials can be explained by several hypotheses; the insufficient local concentration at the infarcted myocardium and the unwanted systemic effects of EPO $(46,47)$.

Based on these facts, our group performed a preclinical study using EPO as a cell-priming agent for PBMCs or PB-MPCs (48). With adoption of an ex vivo cell-priming strategy, we expected several benefits; to maximize the cellular effect of EPO on target cells, while avoiding the systemic side effects of EPO. As a result, cell-priming with EPO induced a shift in monocytes polarization toward $\mathrm{CD} 14(++) / \mathrm{CD} 16(+)$ monocytes, which are so-called vasculogenic/anti-inflammatory monocytes that play a pivotal pro-healing action in debris scavenging, wound healing, and angiogenesis (49). Also, EPO-primed PBMCs could upregulate expression of integrins, which could enhance homing to the infarcted myocardium. In a paracrine matter, EPO-primed PBMCs secreted cytokines such as IL8 and IL10, to form a vasculogenic niche at the target ischemic tissue. Taken together, our results showed that ex vivo EPO-priming augmented the vasculogenic potential of human PBMCs, proving to be a promising and practical method to augment the therapeutic efficacy of PBMCs in cell therapy.

\section{Activated Platelet Supernatant}

Platelets, which are known to play a role in hemostasis, simultaneously promote tissue repair via releasing a vast amount of cytokines and chemokines that favor angiogenesis and wound healing (50). In previous studies, autologous platelets have been used in human clinical trials for bone repair (51), wound healing in ocular surface disease (52), and for cardioprotection from ischemia-reperfusion injury (53). Immediately after an ischemic injury, platelets play a key role in the surge of local cytokines and chemokines, which recruit monocytes to the damaged tissue, stimulate endothelial cell proliferation, and increase vascular permeability (54).

Based on this background, we used the surge of cytokines and chemokines from platelets, the so-called APS, as a priming agent for human PBMCs or PB-MPCs in a previous preclinical study. We could find that APS-primed PBMCs were polarized to M2 monocytes, which could efficiently induce gene expression of angiogenic molecules. Furthermore, APS priming could promote angiogenesis in a paracrine manner, by secreting angiogenic cytokines, such as IL8, IL10, and PDGF (55). Also, in a rat MI model, APS-primed PBMCs could decrease fibrosis area and myocardium wall thinning, which leads to improvement in cardiac function (56).

\section{Hypoxia}

Although not exactly an "agent" but rather a "condition," hypoxia has been used to augment the efficacy of cell therapy. In various preclinical studies, hypoxia could direct embryonic stem cells or PBMCs to differentiate into cardiomyocytes (57), chondrocytes (58), or vascular progenitor cells. In previous preclinical studies, hypoxia priming enhanced the differentiation of embryoid bodies into meso-endodermal cells, which differentiated into vascular-lineage cells more efficiently than normoxic embryoid bodies (59). Also, hypoxic preconditioning to cardiospherederived cell monolayer sheets, increasing the expression of VEGF through the PI3-kinase/Akt signaling pathway, which leads to improved left ventricular function in chronically infarcted hearts (60). Although ischemic preconditioning has been proven to be beneficial, applying this to the clinic is difficult due to the inability to predict the onset of ischemia in the apparently normal persons.

\section{Other Growth Factors}

Other than the priming agents/conditions listed above, various agents have been studied to enhance the therapeutic efficacy of stem cell therapy in MI.

\section{Vascular Endothelial Growth Factor}

Initial research of VEGF, which plays a critical role in angiogenesis (61), was promising in preclinical studies as a therapeutic agent for ischemic disorders. However, clinical trials failed, only to reveal that VEGF offered no improvement in treated patients as compared with placebo (62). These results may have been partially attributed to the short-lived effect and high instability of the protein when injected as a bolus (63). Currently, different methods to deliver VEGF, such as using scaffolds or other biomaterials, are under research.

\section{SDF-1}

The interaction between SDF-1 and CXCR4 plays an important role in vasculogenesis especially for the engraftment and maintenance in situ (64). In preclinical studies, SDF-1 priming of EPCs could enhance adhesion and extravasation of progenitor cells to ischemic sites, promoting firm adherence to activated endothelium (65) and effective to enhance cardioprotective 
effect in animal experiments (66), which need to be confirmed in human studies.

\section{Quality and Quantity Culture}

Due to the limited effect of single agents, there have been trials that used multiple agents for priming. In a previous animal study, EPC populations, such as CD34+ and CD133+ cells, could be enriched by the method for quality and quantity-control culture (QQ culture; a combination of stem cell factor, thrombopoietin, Flt-3 ligand, VEGF, and interleukin-6). Also, priming monocytes under QQ culture induced anti-inflammatory and angiogenic monocytes/helper T lymphocytes (67).

\section{RECENT CLINICAL TRIALS FOR STEM CELL THERAPY IN MI}

Along with a vast amount of preclinical studies, various human clinical trials have tested the efficacy of stem cell therapy in MI. The results varied even though they were conducted under contemporary treatment strategies for MI during the past decade $(6,8,9,68-72)$. Some studies reported positive effects of stem cell therapy, while others failed (Table 1). These conflicting results in clinical studies in contrast to the positive results of preclinical ones emphasize the necessity to augment therapeutic efficacy of stem cell therapy by refining the protocol.

There are several ongoing clinical studies of cell therapy for acute MI, which may report results within the next couple of years (searched from www.clinicaltrials.gov, using keywords of "stem cell" and "myocardial infarction"). These studies include the
EXpanded CELL ENdocardiac Transplantation (EXCELLENT) trial (NCT02669810), which will evaluate the efficacy of intracardiac injection of ProtheraCytes (autologous PB-CD34+ stem cells after automated ex vivo expansion with the StemXpand machine), the A Randomized, Open labEled, muLticenter Trial for Safety and Efficacy of Intracoronary Adult Human Mesenchymal stEm Cells Acute Myocardial inFarction (RELIEF) study (NCT01652209), which will evaluate the efficacy of adult human mesenchymal stem cells, and the Enhanced Angiogenic Cell Therapy - Acute Myocardial Infarction (ENACT-AMI) trial (NCT00936819), which uses autologous progenitor cells by overexpressing eNOS to enhance the function of autologous progenitor cells. Also, the BAMI (The Effect of Intracoronary Reinfusion of Bone Marrow-derived Mononuclear Cells on All-Cause Mortality in Acute Myocardial Infarction) trial (NCT01569178) is currently ongoing to demonstrate whether a single intracoronary infusion of autologous BM-MNC is safe and reduces all-cause mortality in patients with reduced left ventricular ejection fraction after successful reperfusion for acute MI. There trials may give us more specific answers for the efficacy of stem cell treatment on AMI.

\section{THE UNIQUE COMBI-CYTOKINE-BASED AUTOLOGOUS PB-MPCs THERAPY FOR PATIENTS WITH ACUTE MI: MAGIC CELL THERAPY}

During the past 15 years, our institute has performed a series of clinical trials of cytokine-based cell therapy, named the MAGIC

TABLE 1 | Recent human clinical trials for stem cell therapy in MI.

\begin{tabular}{|c|c|c|c|c|}
\hline $\begin{array}{l}\text { Name of study, } \\
\text { reference }\end{array}$ & Cell type & Patients enrolled & $\begin{array}{l}\text { Follow-up } \\
\text { (months) }\end{array}$ & Results \\
\hline $\begin{array}{l}\text { FINCELL, Huikuri } \\
\text { et al. (68) }\end{array}$ & $\mathrm{BM}-\mathrm{MNC}$ & STEMI patients & 6 & $\begin{array}{l}\text { Improvement in LVEF } \\
\text { No difference in adverse clinical events }\end{array}$ \\
\hline $\begin{array}{l}\text { REGENT, Tendera } \\
\text { et al. (69) }\end{array}$ & $\begin{array}{l}\text { Unselected BM-MNC } \\
\text { and selected } \\
{[\mathrm{CD} 34(+) \text { CXCR4(+)] }} \\
\text { BM-MNC }\end{array}$ & $\begin{array}{l}\text { Acute MI with LVEF } \\
<40 \%\end{array}$ & 6 & $\begin{array}{l}\text { No difference in changes of LVEF, left ventricular end-systolic volume, and left } \\
\text { ventricular end-diastolic volume (significant increase of LVEF subgroup of patients } \\
\text { with severe LVEF impairment) } \\
\text { No difference in major cardiovascular event (death, reinfarction, stroke, target } \\
\text { vessel revascularization) }\end{array}$ \\
\hline $\begin{array}{l}\text { BONAMI, Roncalli } \\
\text { et al. ( } 70)\end{array}$ & Autologous BM cells & Acute Ml patients & 3 & Improvement in myocardial viability \\
\hline $\begin{array}{l}\text { LateTIME, Traverse } \\
\text { et al. (9) }\end{array}$ & $\mathrm{BM}-\mathrm{MNC}$ & Ml patients & 6 & $\begin{array}{l}\text { No difference in LVEF, wall motion abnormality of the infarct zone, and border zone } \\
\text { No significant change in LV volumes and infarct volumes }\end{array}$ \\
\hline $\begin{array}{l}\text { APOLLO, Houtgraaf } \\
\text { et al. (72) }\end{array}$ & $\begin{array}{l}\text { Adipose tissue- } \\
\text { derived cells }\end{array}$ & STEMI patients & 6 & $\begin{array}{l}\text { Positive trend toward improved cardiac function, perfusion defect } \\
50 \% \text { reduction of myocardial scar formation } \\
\text { No severe adverse events }\end{array}$ \\
\hline $\begin{array}{l}\text { CADUCEUS, Makkar } \\
\text { et al. (6) }\end{array}$ & $\begin{array}{l}\text { Cardiosphere-derived } \\
\text { cells }\end{array}$ & Ml patients & 6 & $\begin{array}{l}\text { Reduction in scar mass } \\
\text { Increase in viable heart mass, regional contractility, and regional systolic wall } \\
\text { thickening by MRI imaging } \\
\text { No change in end-diastolic volume, end-systolic volume, and LVEF }\end{array}$ \\
\hline $\begin{array}{l}\text { TIME, Traverse } \\
\text { et al. (71) }\end{array}$ & $\mathrm{BM}-\mathrm{MNC}$ & $\begin{array}{l}\text { STEMI patients with } \\
\text { LV dysfunction }\end{array}$ & 6 & No difference in increase of LVEF or global left ventricular function \\
\hline $\begin{array}{l}\text { SWISS-AMI, Sürder D } \\
\text { et al. (8) }\end{array}$ & BM-MNC & STEMI patients & 4 & No improvement in LV function \\
\hline
\end{tabular}

BM-MNC, bone marrow mononuclear cells; LV, left ventricular; LVEF, left ventricular ejection fraction; STEMI, ST segment elevation myocardial infarction. 
cell (Myocardial Regeneration and Angiogenesis in Myocardial Infarction with G-CSF and Intracoronary Stem Cell Infusion) trial. By a series of work, we could demonstrate that intracoronary infusion of PB-MPCs in MI patients is safe and effective in improving cardiac function (7) with persistent efficacy in a 5-year follow-up (73). The plausible mechanism of long-term efficacy comes from the pro-healing effect of cell therapy on the coronary arterial segment implanted with drug-eluting stent (74). Currently, the MAGIC cell therapy has been approved by the Korean government and is being performed in tertiary hospitals. The PB-MPCs that we are using in this MAGIC cell protocol are primed by multiple agents/conditions, based on the results from previous study results.

First, the patient and PB-MPCs are primed in vivo by EPO and G-CSF; each are injected to the patient by (1) intravenous infusion of $4.5 \mu \mathrm{g} / \mathrm{kg}$ darbepoetin (long-acting EPO), (2) subcutaneous G-CSF at $5 \mu \mathrm{g} / \mathrm{kg}$ body weight twice daily for 3 days. Second, priming with autologous APS and hypoxia is achieved in the apheresis process. PB-MPCs are collected under an apheresis system [minimum target cell dose is $2 \times 10^{9}$ monocytes and $7 \times 10^{6} \mathrm{CD} 34(+)$ cells/patient] and by using the mononuclear cell collection method, not only PB-MPCs but also platelets are collected. Platelets are activated by the apheresis process, forming an autologous APS. Therefore, during the short incubation period within the sealed apheresis package, PB-MPCs are primed by APS and also by hypoxia. Overall, we combined various priming/conditions so as to maximize the therapeutic efficacy of PB-MPC cell therapy. The beneficial cellular effects of each single priming agent, based on preclinical studies, are shown in Table 2.

\section{STRENGTH AND LIMITATIONS OF CELL THERAPY IN ISCHEMIC HEART DISEASE}

Stem cells are ideal candidates for use in regenerative medicine because of their ability to differentiate to multiple cell lineages. In the case of ischemic heart diseases, stem cell therapy could regenerate the damaged myocardial or vascular tissue and/or prevent adverse ventricular remodeling after infarction. Current options for reperfusion (e.g., medical treatment, percutaneous coronary intervention, and surgical treatment) have significantly improved outcomes after MI; however, these techniques do not reverse the necrosis process after ischemia. In this aspect, stem cell therapy may provide a unique additional treatment for MI.

Despite the advantages of stem cell therapy, it is important to point out the limitations, so as to prevent unnecessary optimism. First, stem cells are not fully under control; adult stem cells are difficult to expand in culture, whereas embryonic stem cells have the risk of chromosomal abnormalities (75). Sufficient expansion is needed for treatment efficacy, whereas chromosomal abnormalities have the risk of teratoma formation. Also, the adequate type/timing and number of cells delivered at the site of engraftment has not been fully evaluated. Ex vivo expansion of injected cells may be a method to increase efficacy; however, this is a procedure prone to contamination. The most fundamental

TABLE 2 | Study results of priming agents for peripheral blood mononuclear cells or peripheral blood mobilized-progenitor cells from the bone marrow.

\begin{tabular}{|c|c|c|c|c|}
\hline $\begin{array}{l}\text { Priming agent and } \\
\text { priming method }\end{array}$ & Cell species & Animal model & Outcome & Reference \\
\hline $\begin{array}{l}\text { Agent> angiopoietin-1 } \\
\text { (Ang-1) } \\
\text { Method> primed with } \\
\text { COMP-Ang-1 (400 } \mathrm{ng} / \mathrm{ml}) \\
\text { for } 2-4 \mathrm{~h}\end{array}$ & $\begin{array}{l}\text { PBMCs/PB-MPCs } \\
\text { from acute } \\
\text { myocardial infarction } \\
\text { patients }\end{array}$ & $\begin{array}{l}\text { Rabbit ear ischemia } \\
\text { and reperfusion } \\
\text { model } \\
\text { Athymic nude } \\
\text { mouse hind limb } \\
\text { ischemia model }\end{array}$ & $\begin{array}{l}\text { - Increased expression of endothelial cell markers (CD31 and VE-cadherin) and } \\
\text { - Increased Matrigel tube formation and incorporation ability } \\
\text { - Enhanced first-pass engraftment into the distal vascular bed and enhances } \\
\text { neovascularization of the ischemic area (Animal model) }\end{array}$ & (34) \\
\hline $\begin{array}{l}\text { Agent }>\text { erythropoietin } \\
\text { Method }>\text { primed with } \\
\text { Human recombinant EPO } \\
(10 \mathrm{lU} / \mathrm{ml}) \text { for } 6 \mathrm{~h}\end{array}$ & $\begin{array}{l}\text { PBMCs/PB-MPCs } \\
\text { from healthy } \\
\text { volunteers after } \\
\text { 3-day subcutaneous } \\
\text { injection of G-CSF } \\
(10 \mu \mathrm{g} / \mathrm{kg})\end{array}$ & $\begin{array}{l}\text { Athymic nude } \\
\text { mouse hind limb } \\
\text { ischemia model } \\
\text { and myocardial } \\
\text { infarction model }\end{array}$ & $\begin{array}{l}\text { - Increased synthesis of vasculogenesis-related cytokines and integrins (IL8, } \\
\text { IL10, bFGF, PDGF, MMP2, integrin } \alpha \mathrm{V}, \beta 1, \beta 2 \text {, and } \beta 8 \text { ) } \\
\text { - Increased proliferation of CD14(++)/CD16(+) angiogenic mononuclear cells } \\
\text { and reduced apoptotic cells } \\
\text { - Enhance neovascularization in ischemic limb and repair myocardium after } \\
\text { infarction through cellular and humoral mechanisms (Animal model) }\end{array}$ & (43) \\
\hline $\begin{array}{l}\text { Agent }>\text { G-CSF } \\
\text { Method }>\text { in vivo injection }\end{array}$ & Rabbit & $\begin{array}{l}\text { Rabbit myocardial } \\
\text { infarction model }\end{array}$ & $\begin{array}{l}\text { - Upregulation of VEGF, MMP-1, SDF-1 expression within infarcted area } \\
\text { (Animal model) } \\
\text { - Increased CXCR4(+) bone marrow cells and macrophages to infarcted area } \\
\text { (Animal model) } \\
\text { - Reduction of scar area in myocardial infarction model }\end{array}$ & (19) \\
\hline $\begin{array}{l}\text { Agent }>\text { activated platelet } \\
\text { supernatant (APS) } \\
\text { Method }>\text { primed with } \\
\text { APS for } 6 \mathrm{~h}\end{array}$ & $\begin{array}{l}\text { PBMCs/PB-MPCs } \\
\text { from healthy } \\
\text { volunteers after a } \\
\text { 3-day subcutaneous } \\
\text { injection of G-CSF } \\
(10 \mu \mathrm{g} / \mathrm{kg})\end{array}$ & $\begin{array}{l}\text { Athymic nude } \\
\text { mouse hind limb } \\
\text { ischemia model }\end{array}$ & $\begin{array}{l}\text { - Increased gene expression of cytokines (i.e., IL8, IL10, IL13, IL17, bFGF, and } \\
\text { - } \mathrm{TNF} \alpha \text { ) } \\
\text { - Increased CD34(+), CD31(+), Tie2(+), CXCR4(+) cells } \\
\text { - Increased proliferation of CD14(++)/CD16(+) angiogenic mononuclear cells } \\
\text { and reduced apoptotic cells } \\
\text { - Enhanced adhesion and migration activity } \\
\text { - Increased tissue regeneration and angiogenesis (Animal model) }\end{array}$ & (50) \\
\hline
\end{tabular}

COMP, cartilage oligomeric matrix protein; PBMC, peripheral blood mononuclear cell; PB-MPCs, peripheral blood mobilized-progenitor-cells from bone marrow. 
limitation may be that the mechanism of stem cell therapy is not yet fully understood. Unlike the initial expectation that injected stem cells may engraft and transdifferentiate into myocardial cells based on the pluripotency and plasticity, it is understood that the positive effects on cardiac function may have resulted from a paracrine effect (48).

\section{CONCLUSION AND FUTURE DIRECTIONS}

Despite the promising results of cell therapy in preclinical studies, human trials for stem cell therapy in MI patients have shown marginal benefits compared to placebo. However, by understanding the precise mechanism of cardiac repair and by understanding the limitations of current methods for cell therapy, we are observing slow and steady progress. Among the various strategies currently available, priming cells or the host is the most feasible and practical method that can be used at the clinic. Single agents have shown marginal effects, and combination of multiple priming agents may have beneficial effects. Furthermore, future

\section{REFERENCES}

1. Hur J, Yoon CH, Kim HS, Choi JH, Kang HJ, Hwang KK, et al. Characterization of two types of endothelial progenitor cells and their different contributions to neovasculogenesis. Arterioscler Thromb Vasc Biol (2004) 24(2):288-93. doi:10.1161/01.ATV.0000114236.77009.06

2. Hahn JY, Cho HJ, Kang HJ, Kim TS, Kim MH, Chung JH, et al. Pre-treatment of mesenchymal stem cells with a combination of growth factors enhances gap junction formation, cytoprotective effect on cardiomyocytes, and therapeutic efficacy for myocardial infarction. J Am Coll Cardiol (2008) 51(9):933-43. doi:10.1016/j.jacc.2007.11.040

3. Strauer BE, Brehm M, Zeus T, Kostering M, Hernandez A, Sorg RV, et al. Repair of infarcted myocardium by autologous intracoronary mononuclear bone marrow cell transplantation in humans. Circulation (2002) 106(15):1913-8. doi:10.1161/01.CIR.0000034046.87607.1C

4. Wollert KC, Meyer GP, Lotz J, Ringes-Lichtenberg S, Lippolt P, Breidenbach C, et al. Intracoronary autologous bone-marrow cell transfer after myocardial infarction: the BOOST randomised controlled clinical trial. Lancet (2004) 364(9429):141-8. doi:10.1016/S0140-6736(04)16626-9

5. Schachinger V, Erbs S, Elsasser A, Haberbosch W, Hambrecht R, Holschermann $\mathrm{H}$, et al. Intracoronary bone marrow-derived progenitor cells in acute myocardial infarction. $N$ Engl J Med (2006) 355(12):1210-21. doi:10.1056/NEJMoa060186

6. Makkar RR, Smith RR, Cheng K, Malliaras K, Thomson LE, Berman D, et al. Intracoronary cardiosphere-derived cells for heart regeneration after myocardial infarction (CADUCEUS): a prospective, randomised phase 1 trial. Lancet (2012) 379(9819):895-904. doi:10.1016/S0140-6736(12)60195-0

7. Kang HJ, Lee HY, Na SH, Chang SA, Park KW, Kim HK, et al. Differential effect of intracoronary infusion of mobilized peripheral blood stem cells by granulocyte colony-stimulating factor on left ventricular function and remodeling in patients with acute myocardial infarction versus old myocardial infarction: the MAGIC cell-3-DES randomized, controlled trial. Circulation (2006) 114(1 Suppl):I145-51. doi:10.1161/CIRCULATIONAHA. 105.001107

8. Sürder D, Manka R, Lo Cicero V, Moccetti T, Rufibach K, Soncin S, et al. Intracoronary injection of bone marrow-derived mononuclear cells early or late after acute myocardial infarction: effects on global left ventricular function. Circulation (2013) 127(19):1968-79. doi:10.1161/ CIRCULATIONAHA.112.001035

9. Traverse JH, Henry TD, Ellis SG, Pepine CJ, Willerson JT, Zhao DX, et al. Effect of intracoronary delivery of autologous bone marrow mononuclear cells 2 to 3 weeks following acute myocardial infarction on left ventricular function: the LateTIME randomized trial. JAMA (2011) 306(19):2110-9. doi:10.1001/ jama.2011.1670 studies are needed to better define the crucial mechanism of cardiac repair after cell therapy. Identification of the optimal cell type and clarification of the optimal manipulation to the cell is essential for advance in cell therapy for MI.

\section{AUTHOR CONTRIBUTIONS}

All the authors researched data for the article, discussed its content, and wrote, edited, and reviewed the manuscript.

\section{ACKNOWLEDGMENTS}

H-SK is also supported by the Korea Health Technology R\&D Project (HI14C1277) through the Korea Health Industry Development Institute (KHIDI) funded by the Ministry of Health and Welfare (MHW). This study is supported by the Bio and Medical Technology Development Program of the National Research Foundation (NRF) funded by the Korean government (MSIP) (NRF-2015M3A9B4051041 and NRF-2015M3A9B4051198).

10. Lipinski MJ, Biondi-Zoccai GG, Abbate A, Khianey R, Sheiban I, Bartunek J, et al. Impact of intracoronary cell therapy on left ventricular function in the setting of acute myocardial infarction: a collaborative systematic review and meta-analysis of controlled clinical trials. J Am Coll Cardiol (2007) 50(18):1761-7. doi:10.1016/j.jacc.2007.07.041

11. Liu B, Duan CY, Luo CF, Ou CW, Wu ZY, Zhang JW, et al. Impact of timing following acute myocardial infarction on efficacy and safety of bone marrow stem cells therapy: a network meta-analysis. Stem Cells Int (2016) 2016:1031794. doi:10.1155/2016/1031794

12. Fisher SA, Zhang H, Doree C, Mathur A, Martin-Rendon E. Stem cell treatment for acute myocardial infarction. Cochrane Database Syst Rev (2015) (9):CD006536. doi:10.1002/14651858.CD006536.pub4

13. Ebert $\mathrm{AD}$, Diecke S, Chen IY, Wu JC. Reprogramming and transdifferentiation for cardiovascular development and regenerative medicine: where do we stand? EMBO Mol Med (2015) 7(9):1090-103. doi:10.15252/emmm. 201504395

14. Carvalho E, Verma P, Hourigan K, Banerjee R. Myocardial infarction: stem cell transplantation for cardiac regeneration. Regen Med (2015) 10(8):1025-43. doi:10.2217/rme.15.63

15. Kang WJ, Kang HJ, Kim HS, Chung JK, Lee MC, Lee DS. Tissue distribution of 18F-FDG-labeled peripheral hematopoietic stem cells after intracoronary administration in patients with myocardial infarction. J Nucl Med (2006) 47(8):1295-301.

16. Segers VF, Lee RT. Stem-cell therapy for cardiac disease. Nature (2008) 451(7181):937-42. doi:10.1038/nature06800

17. Finan A, Richard S. Stimulating endogenous cardiac repair. Front Cell Dev Biol (2015) 3:57. doi:10.3389/fcell.2015.00057

18. de Almeida PE, Ransohoff JD, Nahid A, Wu JC. Immunogenicity of pluripotent stem cells and their derivatives. Circ Res (2013) 112(3):549-61. doi:10.1161/ CIRCRESAHA.111.249243

19. Krause K, Schneider C, Kuck KH, Jaquet K. Stem cell therapy in cardiovascular disorders. Cardiovasc Ther (2010) 28(5):e101-10. doi:10.1111/ j.1755-5922.2010.00208.x

20. Yoon CH, Koyanagi M, Iekushi K, Seeger F, Urbich C, Zeiher AM, et al. Mechanism of improved cardiac function after bone marrow mononuclear cell therapy: role of cardiovascular lineage commitment. Circulation (2010) 121(18):2001-11. doi:10.1161/CIRCULATIONAHA.109.909291

21. Huang PP, Yang XF, Li SZ, Wen JC, Zhang Y, Han ZC. Randomised comparison of G-CSF-mobilized peripheral blood mononuclear cells versus bone marrow-mononuclear cells for the treatment of patients with lower limb arteriosclerosis obliterans. Thromb Haemost (2007) 98(6):1335-42. doi:10.1160/TH07-02-0137

22. Hopman RK, DiPersio JF. Advances in stem cell mobilization. Blood Rev (2014) 28(1):31-40. doi:10.1016/j.blre.2014.01.001 
23. Demetri GD, Griffin JD. Granulocyte colony-stimulating factor and its receptor. Blood (1991) 78(11):2791-808.

24. Misao Y, Takemura G, Arai M, Ohno T, Onogi H, Takahashi T, et al. Importance of recruitment of bone marrow-derived CXCR4+ cells in post-infarct cardiac repair mediated by G-CSF. Cardiovasc Res (2006) 71(3):455-65. doi:10.1016/ j.cardiores.2006.05.002

25. Harada M, Qin Y, Takano H, Minamino T, Zou Y, Toko H, et al. G-CSF prevents cardiac remodeling after myocardial infarction by activating the JakStat pathway in cardiomyocytes. Nat Med (2005) 11(3):305-11. doi:10.1038/ nm1199

26. Capoccia BJ, Shepherd RM, Link DC. G-CSF and AMD3100 mobilize monocytes into the blood that stimulate angiogenesis in vivo through a paracrine mechanism. Blood (2006) 108(7):2438-45. doi:10.1182/blood-2006-04-013755

27. Pajkrt D, Manten A, van der Poll T, Tiel-van Buul MM, Jansen J, Wouter ten Cate J, et al. Modulation of cytokine release and neutrophil function by granulocyte colony-stimulating factor during endotoxemia in humans. Blood (1997) 90(4):1415-24.

28. Minatoguchi S, Takemura G, Chen XH, Wang N, Uno Y, Koda M, et al. Acceleration of the healing process and myocardial regeneration may be important as a mechanism of improvement of cardiac function and remodeling by postinfarction granulocyte colony-stimulating factor treatment. Circulation (2004) 109(21):2572-80. doi:10.1161/01.CIR.0000129770.93985.3E

29. Sanganalmath SK, Abdel-Latif A, Bolli R, Xuan YT, Dawn B. Hematopoietic cytokines for cardiac repair: mobilization of bone marrow cells and beyond. Basic Res Cardiol (2011) 106(5):709-33. doi:10.1007/s00395-011-0183-y

30. Takano H, Hasegawa H, Kuwabara Y, Nakayama T, Matsuno K, Miyazaki Y, et al. Feasibility and safety of granulocyte colony-stimulating factor treatment in patients with acute myocardial infarction. Int J Cardiol (2007) 122(1):41-7. doi:10.1016/j.ijcard.2006.11.016

31. Kuethe F, Figulla HR, Herzau M, Voth M, Fritzenwanger M, Opfermann T, et al. Treatment with granulocyte colony-stimulating factor for mobilization of bone marrow cells in patients with acute myocardial infarction. Am Heart $J(2005)$ 150(1):115. doi:10.1016/j.ahj.2005.04.030

32. Kang HJ, Kim HS, Zhang SY, Park KW, Cho HJ, Koo BK, et al. Effects of intracoronary infusion of peripheral blood stem-cells mobilised with granulocyte-colony stimulating factor on left ventricular systolic function and restenosis after coronary stenting in myocardial infarction: the MAGIC cell randomised clinical trial. Lancet (2004) 363(9411):751-6. doi:10.1016/ S0140-6736(04)15689-4

33. Ripa RS, Jorgensen E, Wang Y, Thune JJ, Nilsson JC, Sondergaard L, et al. Stem cell mobilization induced by subcutaneous granulocyte-colony stimulating factor to improve cardiac regeneration after acute ST-elevation myocardial infarction: result of the double-blind, randomized, placebo-controlled stem cells in myocardial infarction (STEMMI) trial. Circulation (2006) 113(16):1983-92. doi:10.1161/CIRCULATIONAHA.105.610469

34. Zohlnhofer D, Ott I, Mehilli J, Schomig K, Michalk F, Ibrahim T, et al. Stem cell mobilization by granulocyte colony-stimulating factor in patients with acute myocardial infarction: a randomized controlled trial. JAMA (2006) 295(9):1003-10. doi:10.1001/jama.295.9.1003

35. Engelmann MG, Theiss HD, Theiss C, Henschel V, Huber A, Wintersperger BJ, et al. G-CSF in patients suffering from late revascularised ST elevation myocardial infarction: final 1-year-results of the G-CSF-STEMI Trial. Int J Cardiol (2010) 144(3):399-404. doi:10.1016/j.ijcard.2009.04.047

36. Zohlnhofer D, Dibra A, Koppara T, de Waha A, Ripa RS, Kastrup J, et al. Stem cell mobilization by granulocyte colony-stimulating factor for myocardial recovery after acute myocardial infarction: a meta-analysis. J Am Coll Cardiol (2008) 51(15):1429-37. doi:10.1016/j.jacc.2007.11.073

37. Abdel-Latif A, Bolli R, Zuba-Surma EK, Tleyjeh IM, Hornung CA, Dawn B. Granulocyte colony-stimulating factor therapy for cardiac repair after acute myocardial infarction: a systematic review and meta-analysis of randomized controlled trials. Am Heart J (2008) 156(2):216-26e9. doi:10.1016/ j.ahj.2008.03.024

38. Thurston G, Rudge JS, Ioffe E, Zhou H, Ross L, Croll SD, et al. Angiopoietin-1 protects the adult vasculature against plasma leakage. Nat Med (2000) 6(4):460-3. doi:10.1038/74725

39. Kim MS, Lee CS, Hur J, Cho HJ, Jun SI, Kim TY, et al. Priming with angiopoietin-1 augments the vasculogenic potential of the peripheral blood stem cells mobilized with granulocyte colony-stimulating factor through a novel Tie2/Ets-1 pathway. Circulation (2009) 120(22):2240-50. doi:10.1161/ CIRCULATIONAHA.109.856815

40. Broxmeyer HE. Erythropoietin: multiple targets, actions, and modifying influences for biological and clinical consideration. JExp Med (2013) 210(2):205-8. doi:10.1084/jem.20122760

41. Maiese K, Li F, Chong ZZ. New avenues of exploration for erythropoietin. JAMA (2005) 293(1):90-5. doi:10.1001/jama.293.1.90

42. Burger D, Xenocostas A, Feng QP. Molecular basis of cardioprotection by erythropoietin. Curr Mol Pharmacol (2009) 2(1):56-69. doi:10.2174/187446 7210902010056

43. Najjar SS, Rao SV, Melloni C, Raman SV, Povsic TJ, Melton L, et al. Intravenous erythropoietin in patients with ST-segment elevation myocardial infarction: REVEAL: a randomized controlled trial. JAMA (2011) 305(18):1863-72. doi:10.1001/jama.2011.592

44. Voors AA, Belonje AM, Zijlstra F, Hillege HL, Anker SD, Slart RH, et al. A single dose of erythropoietin in ST-elevation myocardial infarction. Eur Heart J (2010) 31(21):2593-600. doi:10.1093/eurheartj/ehq304

45. Suh JW, Chung WY, Kim YS, Kim KI, Jeon EJ, Cho YS, et al. The effect of intravenous administration of erythropoietin on the infarct size in primary percutaneous coronary intervention. Int J Cardiol (2011) 149(2):216-20. doi:10.1016/j.ijcard.2010.02.002

46. Taniguchi N, Nakamura T, Sawada T, Matsubara K, Furukawa K, Hadase M, et al. Erythropoietin prevention trial of coronary restenosis and cardiac remodeling after ST-elevated acute myocardial infarction (EPOC-AMI): a pilot, randomized, placebo-controlled study. Circ J (2010) 74(11):2365-71. doi:10.1253/circj.CJ-10-0267

47. Kagaya Y, Asaumi Y, Wang W, Takeda M, Nakano M, Satoh K, et al. Current perspectives on protective roles of erythropoietin in cardiovascular system: erythropoietin receptor as a novel therapeutic target. Tohoku J Exp Med (2012) 227(2):83-91. doi:10.1620/tjem.227.83

48. Kang J, Yun JY, Hur J, Kang JA, Choi JI, Ko SB, et al. Erythropoietin priming improves the vasculogenic potential of G-CSF mobilized human peripheral blood mononuclear cells. Cardiovasc Res (2014) 104(1):171-82. doi:10.1093/ $\mathrm{cvr} / \mathrm{cvu} 180$

49. Ho VW, Sly LM. Derivation and characterization of murine alternatively activated (M2) macrophages. Methods Mol Biol (2009) 531:173-85. doi:10.1007/978-1-59745-396-7_12

50. Blair P, Flaumenhaft R. Platelet alpha-granules: basic biology and clinical correlates. Blood Rev (2009) 23(4):177-89. doi:10.1016/j.blre.2009.04.001

51. Kreuz PC, Kruger JP, Metzlaff S, Freymann U, Endres M, Pruss A, et al. Platelet-rich plasma preparation types show impact on chondrogenic differentiation, migration, and proliferation of human subchondral mesenchymal progenitor cells. Arthroscopy (2015) 31(10):1951-61. doi:10.1016/ j.arthro.2015.03.033

52. Alio JL, Arnalich-Montiel F, Rodriguez AE. The role of "eye platelet rich plasma" (E-PRP) for wound healing in ophthalmology. Curr Pharm Biotechnol (2012) 13(7):1257-65. doi:10.2174/138920112800624355

53. Yang B, Mehta P, Mehta JL. Platelet-mediated cardioprotective effect against ischemia-reperfusion injury in isolated rat hearts: role of platelet number and contribution of supernatant of aggregated platelets. J Cardiovasc Pharmacol Ther (1998) 3(1):23-8. doi:10.1053/jcpt.1998.0023

54. Rohde E, Malischnik C, Thaler D, Maierhofer T, Linkesch W, Lanzer G, et al. Blood monocytes mimic endothelial progenitor cells. Stem Cells (2006) 24(2):357-67. doi:10.1634/stemcells.2005-0072

55. Kang J, Hur J, Kang JA, Yun JY, Choi JI, Ko SB, et al. Activated platelet supernatant can augment the angiogenic potential of human peripheral blood stem cells mobilized from bone marrow by G-CSF. J Mol Cell Cardiol (2014) 75:64-75. doi:10.1016/j.yjmcc.2014.06.019

56. Kang J, Hur J, Kang JA, Lee HS, Jung H, Choi JI, et al. Priming mobilized peripheral blood mononuclear cells with the "activated platelet supernatant" enhances the efficacy of cell therapy for myocardial infarction of rats. Cardiovasc Ther (2016) 34(4):245-53. doi:10.1111/1755-5922.12194

57. Niebruegge S, Bauwens CL, Peerani R, Thavandiran N, Masse S, Sevaptisidis E, et al. Generation of human embryonic stem cell-derived mesoderm and cardiac cells using size-specified aggregates in an oxygen-controlled bioreactor. Biotechnol Bioeng (2009) 102(2):493-507. doi:10.1002/bit.22065

58. Koay EJ, Athanasiou KA. Hypoxic chondrogenic differentiation of human embryonic stem cells enhances cartilage protein synthesis and biomechanical 
functionality. Osteoarthritis Cartilage (2008) 16(12):1450-6. doi:10.1016/ j.joca.2008.04.007

59. Lee SW, Jeong HK, Lee JY, Yang J, Lee EJ, Kim SY, et al. Hypoxic priming of mESCs accelerates vascular-lineage differentiation through HIF1-mediated inverse regulation of Oct4 and VEGF. EMBO Mol Med (2012) 4(9):924-38. doi:10.1002/emmm.201101107

60. Hosoyama T, Samura M, Kudo T, Nishimoto A, Ueno K, Murata T, et al. Cardiosphere-derived cell sheet primed with hypoxia improves left ventricular function of chronically infarcted heart. Am J Transl Res (2015) 7(12):2738-51.

61. Riley PR, Smart N. Vascularizing the heart. Cardiovasc Res (2011) 91(2):260-8. doi:10.1093/cvr/cvr035

62. Henry TD, Annex BH, McKendall GR, Azrin MA, Lopez JJ, Giordano FJ, et al. The VIVA trial: vascular endothelial growth factor in ischemia for vascular angiogenesis. Circulation (2003) 107(10):1359-65. doi:10.1161/01. CIR.0000061911.47710.8A

63. Simon-Yarza T, Formiga FR, Tamayo E, Pelacho B, Prosper F, Blanco-Prieto MJ. Vascular endothelial growth factor-delivery systems for cardiac repair: an overview. Theranostics (2012) 2(6):541-52. doi:10.7150/thno.3682

64. Jin H, Aiyer A, Su J, Borgstrom P, Stupack D, Friedlander M, et al. A homing mechanism for bone marrow-derived progenitor cell recruitment to the neovasculature. J Clin Invest (2006) 116(3):652-62. doi:10.1172/JCI24751

65. Zemani F, Silvestre JS, Fauvel-Lafeve F, Bruel A, Vilar J, Bieche I, et al. Ex vivo priming of endothelial progenitor cells with SDF-1 before transplantation could increase their proangiogenic potential. Arterioscler Thromb Vasc Biol (2008) 28(4):644-50. doi:10.1161/ATVBAHA.107.160044

66. Frederick JR, Fitzpatrick JR III, McCormick RC, Harris DA, Kim AY, Muenzer JR, et al. Stromal cell-derived factor-1alpha activation of tissue-engineered endothelial progenitor cell matrix enhances ventricular function after myocardial infarction by inducing neovasculogenesis. Circulation (2010) 122(11 Suppl):S107-17. doi:10.1161/CIRCULATIONAHA.109.930404

67. Masuda H, Tanaka R, Fujimura S, Ishikawa M, Akimaru H, Shizuno T, et al. Vasculogenic conditioning of peripheral blood mononuclear cells promotes endothelial progenitor cell expansion and phenotype transition of anti-inflammatory macrophage and $\mathrm{T}$ lymphocyte to cells with regenerative potential. J Am Heart Assoc (2014) 3(3):e000743. doi:10.1161/JAHA.113.000743

68. Huikuri HV, Kervinen K, Niemela M, Ylitalo K, Saily M, Koistinen P, et al. Effects of intracoronary injection of mononuclear bone marrow cells on left ventricular function, arrhythmia risk profile, and restenosis after thrombolytic therapy of acute myocardial infarction. Eur Heart J (2008) 29(22):2723-32. doi:10.1093/eurheartj/ehn436

69. Tendera M, Wojakowski W, Ruzyllo W, Chojnowska L, Kepka C, Tracz W, et al. Intracoronary infusion of bone marrow-derived selected CD34+CXCR4+ cells and non-selected mononuclear cells in patients with acute STEMI and reduced left ventricular ejection fraction: results of randomized, multicentre Myocardial Regeneration by Intracoronary Infusion of Selected Population of Stem Cells in Acute Myocardial Infarction (REGENT) Trial. Eur Heart $J$ (2009) 30(11):1313-21. doi:10.1093/eurheartj/ehp073

70. Roncalli J, Mouquet F, Piot C, Trochu JN, Le Corvoisier P, Neuder Y, et al. Intracoronary autologous mononucleated bone marrow cell infusion for acute myocardial infarction: results of the randomized multicenter BONAMI trial. Eur Heart J (2011) 32(14):1748-57. doi:10.1093/eurheartj/ ehq455

71. Traverse JH, Henry TD, Pepine CJ, Willerson JT, Zhao DX, Ellis SG, et al. Effect of the use and timing of bone marrow mononuclear cell delivery on left ventricular function after acute myocardial infarction: the TIME randomized trial. JAMA (2012) 308(22):2380-9. doi:10.1001/jama.2012.28726

72. Houtgraaf JH, den Dekker WK, van Dalen BM, Springeling T, de Jong R, van Geuns RJ, et al. First experience in humans using adipose tissue-derived regenerative cells in the treatment of patients with ST-segment elevation myocardial infarction. J Am Coll Cardiol (2012) 59(5):539-40. doi:10.1016/ j.jacc.2011.09.065

73. Kang HJ, Kim MK, Lee HY, Park KW, Lee W, Cho YS, et al. Five-year results of intracoronary infusion of the mobilized peripheral blood stem cells by granulocyte colony-stimulating factor in patients with myocardial infarction. Eur Heart J (2012) 33(24):3062-9. doi:10.1093/eurheartj/ehs231

74. Cho HJ, Kim HS, Lee MM, Kim DH, Yang HJ, Hur J, et al. Mobilized endothelial progenitor cells by granulocyte-macrophage colony-stimulating factor accelerate reendothelialization and reduce vascular inflammation after intravascular radiation. Circulation (2003) 108(23):2918-25. doi:10.1161/ 01.CIR.0000097001.79750.78

75. Ghosh Z, Huang M, Hu S, Wilson KD, Dey D, Wu JC. Dissecting the oncogenic and tumorigenic potential of differentiated human induced pluripotent stem cells and human embryonic stem cells. Cancer Res (2011) 71(14):5030-9. doi:10.1158/0008-5472.CAN-10-4402

Conflict of Interest Statement: All authors declare no conflicts of interest, financial or otherwise, in the writing of this manuscript.

Copyright $\odot 2016$ Kang, Kim, Hur and Kim. This is an open-access article distributed under the terms of the Creative Commons Attribution License (CC BY). The use, distribution or reproduction in other forums is permitted, provided the original author(s) or licensor are credited and that the original publication in this journal is cited, in accordance with accepted academic practice. No use, distribution or reproduction is permitted which does not comply with these terms. 